\title{
ОСОБЛИВОСТІ ПРОВЕДЕННЯ ЕКОНОМІКО - МАТЕМАТИЧНОГО ДОСЛІДЖЕННЯ ПОТРЕБ СПОЖИВАЧІВ (ПОПИТУ) ТА ЗБУТУ ТОВАРІВ (ПРОПОЗИЦІЯ) НА ПРИКЛАДІ РИНКУ ХАРЧОВОЇ ПРОДУКЦІї
}

\section{Шериенюк О.М., канд. екон. наук, доцент \\ Прокопенко М.В. , старший викладач \\ Харківський національний автомобільно-дорожній університет;}

Постановка проблеми. Економічні дослідження потреб споживачів (попиту) стають органічною частиною виробничо-збутової діяльності підприємства і повинні здійснюватися постійно, тому що тільки безупинно обновлювана інформація дає уявлення про передбачувані і реальні результати заходів і динаміку їх впливу на зовнішній ринок та споживачів, а також можливість ефективно управляти збутовою діяльністю підприємства.

Важливість та практична цінність економічних досліджень полягає ще й в тому, що вони показують початкові реакції на заходи і зародження економічних процесів, допомагають виробнику налагодити обмін інформацією 3 різними елементами ринку та власними структурами, залучити до своїх дій широке коло фахівців на всіх рівнях, одержати представлення про їх реакцію на запропоновані дії, стимулювати пошук, висування й оперативне пророблення робочих ідей та задумів.

Закордонна практика свідчить, що виробник одержує безліч корисних для управління своєю діяльністю даних навіть у результаті звичайних досліджень: кон'юнктурного аналізу ринку, кон'юнктурного аналізу товару, сегментаційного аналізу споживача.

Отже, за результатами економічних досліджень підприємства зможуть одержати інформацію, що допоможе сформулювати стратегію практичних заходів, створивши базу тривалого використання для стратегічного планування діяльності підприємства в цілому.

Зазначеним вище доводиться актуальність проблеми та необхідність докладного дослідження даного питання.

Аналіз останніх досліджень і публікацій. Дослідження людських потреб (попиту) - це систематичне визначення повного переліку вхідних даних (інформації), необхідних для успішної комерційної діяльності підприємства, їх збір, аналіз та звіт про результати.

В цілому дослідження можна визначити як процес систематичного дослідження потреб споживача з метою встановлення поточного потенційного попиту на споживчі й промислові продукти, забезпечення бази для прийняття управлінських рішень. 
Вагомий внесок в дану проблематику внесли такі вчені як П. Котлер, Дж. Еванс, Д Робинсон. Різні аспекти цього процесу розглядають вітчизняні вчені: Н.С. Краснокутська, Л.В. Балабанова, Ю.П. Митрохіна, М.В. Вачевський, М.I. Долішній, С.Г. Скотний та інші. [1, 2, 3].

Широке коло вчених розглядають економічні дослідження як систематичне визначення кола даних, необхідних для вирішення завдань, що стоять перед фірмою, їх збір, аналіз та звіт про результати.

Таким чином дослідження - систематичний збір, відображення й аналіз даних про проблеми, пов'язаних з попитом і пропозицією товарів та послуг. Крім того, це комплексне поняття, що включає всі види дослідницької діяльності, пов'язані з управлінням.

Як в закордонних, так i в вітчизняних роботах не розглядаються проблеми економічного дослідження в умовах тактичного та стратегічного розвитку пропозиції, що $\epsilon$, на наш погляд, особливо важливим в даний час. Сучасні економічні дослідження повинні бути пов'язані з прийняттям рішення по всій збутовій діяльності, стосуватися всіх елементів пропозиції товарів, послуг та зовнішнього середовища фірми.

Тому при здійсненні економічних досліджень необхідний науковий підхід, що базується на об'єктивності, точності і математичної статистики [4].

Невирішені складові загальної проблеми. Для прийняття фірмою рішення щодо вибору характеристик товару, що випускається (пропозиція) важливе значення мають:

- розробка та затвердження цілей діяльності фірми на майбутній період, зокрема відносно попиту та пропозиції;

- аналіз потреб та бажань споживача, аналіз ринку (попиту та пропозиції конкретних видів товарів та послуг);

- перспективи розвитку даного різновиду товарів та послуг;

- неупереджена оцінка виробничих можливостей підприємства.

На даний час при проведенні економічних досліджень методи широкого анкетування та математико - статистичної обробки отриманих даних використовуються вкрай обмежено (особливо у малому та середньому бізнесі), що призводить до отримання помилкових рішень та економічних втрат.

Формування цілей статті. Мета дослідження полягає в розробці шляхів підвищення ефективності прийняття рішень щодо пропозиції товарів та послуг на основі проведення економічних досліджень попиту та пропозиції на основі економіко - математичних методів (на прикладі ринку продуктів харчування).

Виклад основного матеріалу дослідження. Для позиціонування продукту на ринку, виявлення та вибору сегментів ринку велике значення має характеристика та моделювання купівельної поведінки, виявлення думок i переваг споживачів, мотивації покупок. Інформаційною базою цього аналізу служать опитування споживачів та посередників, інформація торговельних кореспондентів, матеріали отримані в процесі пробного дослідження тощо.

Продукти харчування відносяться до товарів, які споживачі найчастіше вибирають самі. В зв'язку з цим споживчі оцінки мають стратегічне значення, 
як для виробників, так і для фірм, що беруть участь у збуті. Остаточне та реальне позиціювання товару здійснюється у свідомості споживача. Ціннісні орієнтації та уявлення людей неможливо змінити за допомогою маркетингу та регулювання пропозиції, тому важливо, щоб продукція по своїх товарних якостях гармоніювала з запитами та потребами споживачів. У зв'язку з цим важливим $€$ аналіз складу реальних покупців та їх мотивацій при придбанні.

Таким чином, ціль економічного дослідження - аналіз впливу якісних та товарних характеристик на вибір покупців, а також виявлення закономірностей в структурі переваг окремих категорій споживачів на прикладі ринку кондитерських виробів (шоколаду) [5].

В ході досліджень була використана анкета з наступними питаннями.

1. Вік.

2. Сімейний стан.

1. Потреба в покупці.

2. Рівень доходів.

3. Сорт виробу, що купується.

4. Джерело інформації про продукт (реклама, рекомендації фахівців, власна думка).

5. Важливість окремих параметрів (смакові якості; натуральність продукту; ціна; виробник; популярність тощо).

В результаті опитування 100 чоловік було виявлено, що близько 40\% респондентів віддають перевагу кондитерським виробам, зробленим одним виробником.

Серед опитаних споживачів переважають групи покупців із середнім грошовим доходом (50\%), споживачі 3 високим грошовим доходом представлені майже $1 / 3$ респондентів (29\%), на частку споживачів 3 низьким грошовим доходом приходиться майже $1 / 4$ респондентів (21\%).

Серед опитаних споживачів рівномірно розподілені всі вікові групи. Однак варто врахувати, що велику кількість продуктів купують батьки для дітей. Дані сегментації дозволили визначити, що респонденти, які мають дітей, мають потребу в покупці даного виду продукту частіше, ніж бездітні родини.

Також була встановлена залежність: у респондентів, що мають високий та середній рівень доходів, у щоденному раціоні харчування присутні різноманітні сорти кондитерських виробів (від найдешевшого до найдорожчого), на відміну від споживачів з низьким рівнем доходів, що купують їх час від часу, причому віддають перевагу найдешевшим сортам.

Близько 75\% споживачів приймають рішення про покупку самостійно, інші здійснюють покупку за рекомендацією спеціаліста або прямою вказівкою (рис. 1). 


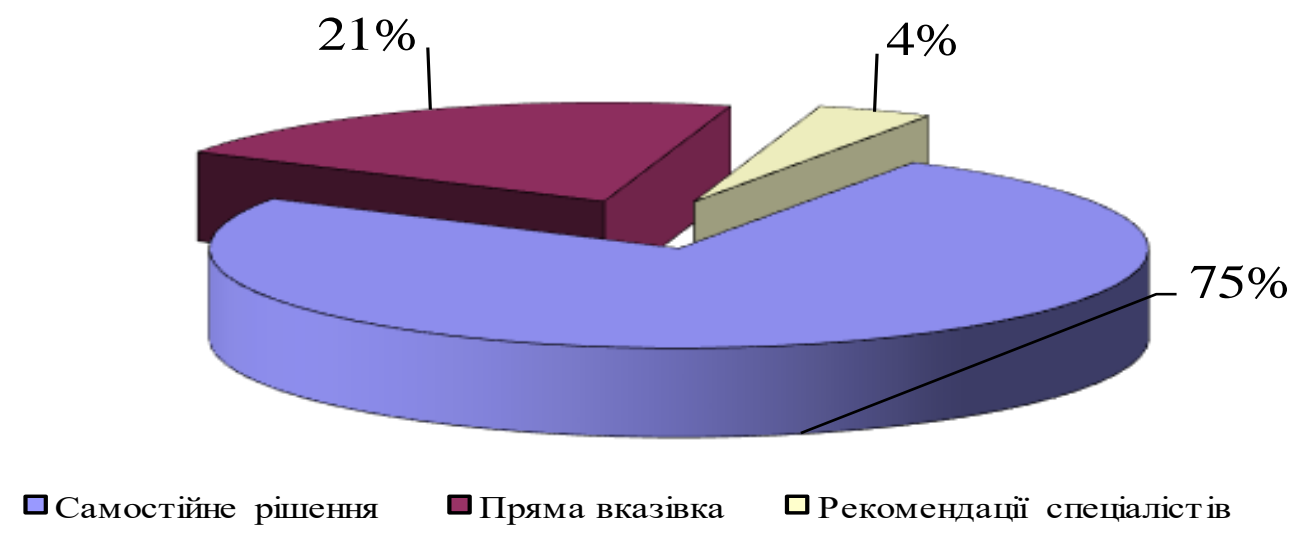

Рис. 1. Рішення про покупку

Джерело: авторська розробка

Що стосується продукту, то для 90\% респондентів одним з основних джерел інформації про нього була реклама, що в значній мірі визначила вибір майже $60 \%$ респондентів. Серед різних видів реклами споживачі відзначили вплив інтернет - роликів та реклами на транспорті.

Ціна поряд зі смаковими якостями $є$ одним 3 найбільш важливих факторів, що впливають на вибір покупця. При цьому думки споживачів розділилися: одна частина респондентів (більш половини опитаних) розглядає ціну як показник якості; інша, змушена заощаджувати грошові кошти, враховує ціну як вирішальний фактор при здійсненні покупки.

Наступним критерієм вибору за ступенем важливості є натуральність продукту.

П'яте і шосте місце за ступенем впливу на вибір споживачів займають термін та умови зберігання продукту.

Маса та розмір тари (упаковка), а також іï дизайн як ознаки що характеризують надійність збереження продукту та зручності використання мають не останнє значення при виборі названої групи товарів. Також вплив на процес ухвалення рішення про покупку робить популярність продукту.

Економічне становище індивіду в значній мірі позначається на його товарному виборі, у зв'язку з цим оцінка споживчих властивостей товару, який купується споживачами 3 високими доходами, істотно відрізняється від загальної структури переваг.

Основну увагу цей сегмент споживачів звертає поряд зі смаковими якостями та натуральністю продукту на такі критерії як: тип упакування, дизайн упакування, виробник (рис. 2). 


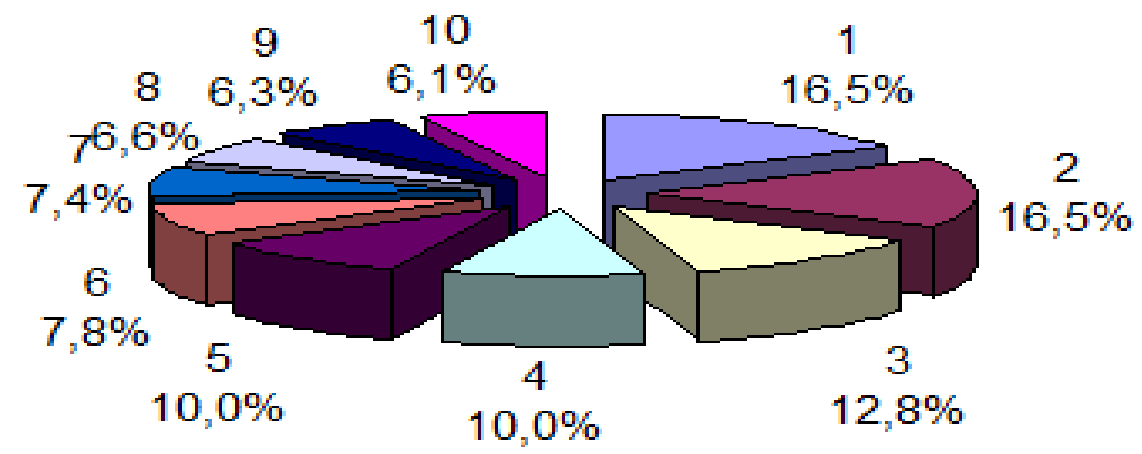
1. Смакові якості
6. Умови збереження
2. Ціна
3. Натуральність продукту
7. Виробник
4. Особливість продукту
8. Маса і розмір упакування
5. Термін збереження
9. Дизайн упакування
10. Популярність продукту

Рис. 2. Розподіл ступеню важливості окремих параметрів для споживачів

Джерело: авторська розробка

Для того щоб дізнатися, якою мірою продукт відповідає очікуванням споживачів, була розроблена ще одна анкета, по якій були опитані респонденти, що віддають перевагу шоколаду визначеної марки.

В анкеті до кожного питання приводилася шкала (п'ятибальна), де потрібно було проставити бали відповідно до оцінки, що виставляє респондент:

- смакові якості продукту;

- натуральність продукту;

- ергономічні властивості;

- відповідність якості продукту його ціні;

- загальна оцінка продукту.

Потім за результатами анкетування була розроблена модель відповідності якості продукту чеканням покупців (табл. 1).

Середні бали параметрів і продукту по кожній групі респондентів визначалися за формулою простої середньоарифметичної, а відповідні показники по всій сукупності - за формулою середньоарифметичної зваженої. У якості «ваг» використовувалися частості розподілу респондентів (по групі, що відповіли «не можу вирішити» за бал приймався 0) [8].

Розкид думок оцінювався за формулою коефіцієнта варіації балів; він склав $26 \%$, що являє собою значну величину.

Як бачимо за результатами дослідження, 71\% респондентів вважають, що якість шоколаду відповідає його ціні повною мірою; $17 \%$ споживачів знаходять, що якість продукції даної торговельної марки не повною мірою відповідає іiі ціні; а 10\% респондентів змушені купувати шоколад даного виробника тільки через його дешевину, тобто ця група споживачів, вважає, що якість шоколаду не відповідає його ціні. 
Таблиия 1

Відповідності якості чеканням покупців

\begin{tabular}{|c|c|c|c|c|c|c|}
\hline \multirow[b]{2}{*}{$\begin{array}{c}\text { Групи покупців, } \\
\text { що оцінили } \\
\text { продукт як }\end{array}$} & \multirow[b]{2}{*}{$\begin{array}{c}\text { Кількість } \\
\text { відповівших, } \\
\text { \% до } \\
\text { підсумку }\end{array}$} & \multicolumn{4}{|c|}{ Середні бали параметрів } & \multirow[b]{2}{*}{$\begin{array}{c}\text { Середній бал } \\
\text { продукту }\end{array}$} \\
\hline & & 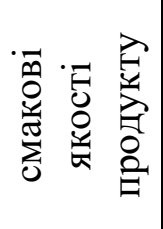 & 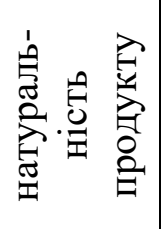 & 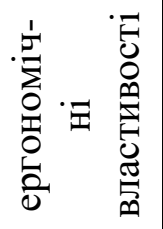 & 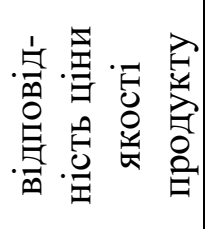 & \\
\hline Дуже гарний & 20 & 4,8 & 4,9 & 4,6 & 4,2 & 4,6 \\
\hline Хороший & 51 & 4,4 & 4,7 & 4,0 & 3,8 & 4,2 \\
\hline Середній & 17 & 3,9 & 3,7 & 4,1 & 3,6 & 3,8 \\
\hline Поганий & 8 & 2,7 & 2,3 & 3,3 & 2,5 & 2,7 \\
\hline Дуже поганий & 2 & 1,4 & 1,8 & 2,0 & 1,1 & 1,6 \\
\hline $\begin{array}{l}\text { Не можу } \\
\text { вирішити }\end{array}$ & 2 & - & - & - & - & - \\
\hline $\begin{array}{l}\text { У цілому по } \\
\text { сукупності } \\
\text { опитаних } \\
\end{array}$ & 100 & 4,16 & 4,27 & 4,01 & 3,65 & 4,00 \\
\hline $\begin{array}{l}\text { Відхилення від } \\
\text { максимальних } \\
\text { очікувань } \\
\text { покупців (від } 5 \\
\text { балів) }\end{array}$ & - & $-0,84$ & $-0,73$ & $-0,99$ & $-1,35$ & $-1,00$ \\
\hline
\end{tabular}

Джерело: авторська розробка

Більшість підприємств-виготовлювачів при виробництві варіюють 2 основних параметри: вміст какао та сорт [6].

Побудуємо поле позиціонування для зазначених головних параметрів [7].

Поле позиціонування являє собою декартову систему координат, де по осі абсцис відкладається вміст какао, по осі ординат вид. На поле відкладаємо точкові значення запитів опитаних споживачів (рис. 3).

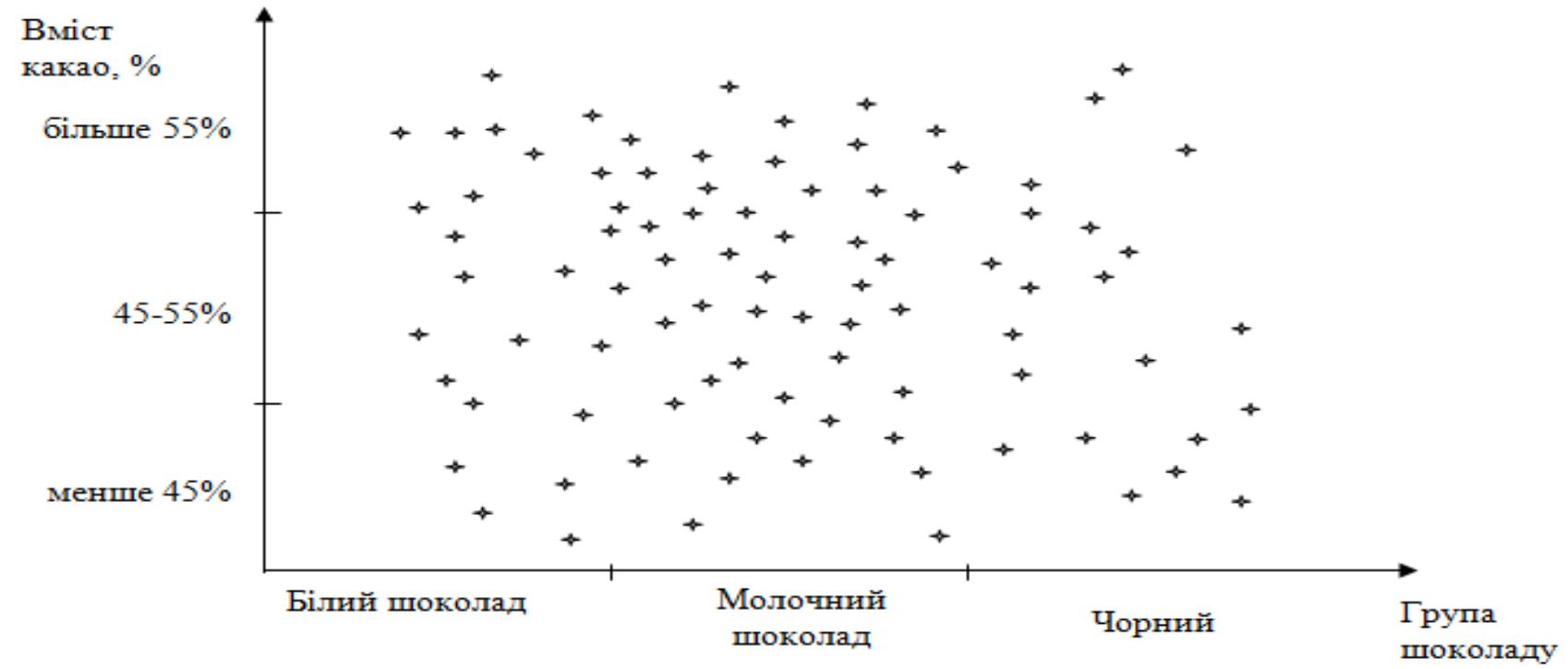

Рис. 3 Поле позиціонування шоколаду

Джерело: авторська розробка 
На підставі поля позиціонування заповнюємо табл. 2.

Таблиия 2

Результати обробки поля позиціонування

\begin{tabular}{|c|c|c|c|}
\hline \multicolumn{2}{|c|}{ Параметр №1 - Вміст какао } & \multicolumn{2}{|c|}{ Параметр №2 - Група } \\
\hline $\begin{array}{c}\text { Інтервали } \\
\text { значень }\end{array}$ & $\begin{array}{c}\text { Кількість точечних } \\
\text { значень попиту }\end{array}$ & $\begin{array}{c}\text { Інтервали } \\
\text { значень }\end{array}$ & $\begin{array}{c}\text { Кількість точечних } \\
\text { значень попиту }\end{array}$ \\
\hline Менше 45\% & 23,1 & Білий шоколад & 28,2 \\
\hline $45-55 \%$ & 26,4 & $\begin{array}{c}\text { Молочний } \\
\text { шоколад }\end{array}$ & 51,6 \\
\hline Більше 55\% & 30,7 & $\begin{array}{c}\text { Чорний } \\
\text { шоколад }\end{array}$ & 20,2 \\
\hline
\end{tabular}

Джерело: авторська розробка

При позиціонуванні шоколаду на ринку найбільш доцільним $є$ вибір сегменту, якому відповідають шоколад 3 вмістом какао більш 55\%, що відносяться до групи молочного шоколаду. Подібний вибір можна обгрунтувати в такий спосіб:

- досить великий обсяг вільної частки ринку, що забезпечить фірмі в перший період діяльності гарантований збут продукції;

- як показали дослідження більшість покупців готові купувати подібний шоколад, а отже $є$ потенційна можливість розширити свою частку ринку за рахунок конкурентів з іншою продукцією.

Аналіз реакції ринку на зміну попиту та пропозииії.

Ринок чуйно реагує на зовнішні впливи. Сприятливий вплив змушує ринок оживлятися та розширюватися, дія негативних сил приводить до скорочення ділової активності, стиску ринку. Особливо піддані впливу такі ринкові категорії, як попит та пропозиція. Попит та пропозиція мінливі i реактивні. Це явище прийняте називати еластичністю [9].

Еластичність попиту/пропозиції - реакція ринку на різнобічні впливи, насамперед на зміну якості, споживчих очікувань, цін та доходу.

Визначимо коефіцієнти цінової еластичності попиту та пропозиції за наступними формулами:

$$
\begin{aligned}
& E_{d}=\frac{D_{1}-D_{2}}{\frac{D_{1}+D_{2}}{2} \div \frac{P_{1}-P_{2}}{P_{1}+P_{2}}}, \\
& E_{s}=\frac{S_{1}-S_{2}}{\frac{S_{1}+S_{2}}{2}} \div \frac{P_{1}-P_{2}}{P_{1}+P_{2}} \\
& 2
\end{aligned}
$$

де $D_{1}, S_{1}-$ значення попиту та пропозиції при ціні $P_{1}$;

$D_{2}, S_{2}-$ значення попиту та пропозиції при ціні $P_{2}$. 
Результати розрахунків та опис характеру еластичності зведемо в таблиці 3 та 4.

Таблиця 3.

Аналіз еластичності попиту за ціною

\begin{tabular}{|c|c|c|c|}
\hline Попит, т & Ціна, грн. & $\begin{array}{c}\text { Коефіцієнт } \\
\text { еластичності }\end{array}$ & Характер еластичності \\
\hline $\mathrm{D}_{1}=2315,6$ & $\mathrm{P}_{1}=10983,20$ & $\mathrm{E}_{1}=2,25$ & Еластичний попит \\
\hline $\mathrm{D}_{2}=2542,4$ & $\mathrm{P}_{2}=11461,95$ & $\mathrm{E}_{2}=2,25$ & Еластичний попит \\
\hline $\mathrm{D}_{3}=1602,5$ & $\mathrm{P}_{3}=14063,11$ & & \\
\hline
\end{tabular}

Джерело: авторська розробка.

Таблиия 4.

Аналіз еластичності пропозиції за ціною

\begin{tabular}{|c|c|c|c|}
\hline Пропозиція, т & Ціна, грн. & $\begin{array}{c}\text { Коефіцієнт } \\
\text { еластичності }\end{array}$ & Характер еластичності \\
\hline $\mathrm{S}_{1}=2708.5$ & $\mathrm{P}_{1}=10983,20$ & $\mathrm{E}_{1}=4,5$ & Еластична пропозиція \\
\hline $\mathrm{S}_{2}=4873.1$ & $\mathrm{P}_{2}=11461,95$ & $\mathrm{E}_{2}=1,25$ & Еластична пропозиція \\
\hline $\mathrm{S}_{3}=6276.9$ & $\mathrm{P}_{3}=14063,11$ & & \\
\hline
\end{tabular}

Джерело: авторська розробка

Оцінимо еластичність попиту по показнику загальної виручки. Якщо попит еластичний, то зменшення ціни приводить до збільшення загального виторгу, в противному випадку - загальна сума виручки скорочується. Результати аналізу зведемо в таблицю 5.

$$
E_{d}=\frac{D_{1}-D_{2}}{\frac{D_{1}+D_{2}}{2}} \div \frac{R_{1}-R_{2}}{\frac{R_{1}+R_{2}}{2}},
$$

де $D_{1}-$ значення попиту при доході $R_{1}$;

$D_{2}$ - значення попиту при доході $R_{2}$ [10].

Таблиия 5.

\section{Аналіз еластичності попиту по доходу}

\begin{tabular}{|c|c|c|c|c|}
\hline Попит, т & Ціна, грн. & Дохід, т.грн. & $\begin{array}{c}\text { Коефіцієнт } \\
\text { еластичності }\end{array}$ & Характер еластичності \\
\hline $\mathrm{D}_{1}=2315,6$ & $\mathrm{P}_{1}=10983,20$ & $\mathrm{R}_{1}=25432,7$ & $\mathrm{E}_{1}=0,6$ & Нееластичний попит \\
\hline $\mathrm{D}_{2}=2542,4$ & $\mathrm{P}_{2}=11461,95$ & $\mathrm{R}_{2}=29140,9$ & $\mathrm{E}_{2}=1,7$ & Еластичний попит \\
\hline $\mathrm{D}_{3}=1602,5$ & $\mathrm{P}_{3}=14063,11$ & $\mathrm{R}_{3}=22536,1$ & - & - \\
\hline
\end{tabular}

Джерело: авторська розробка 
За допомогою інструменту «Регресія» пакету MsExcel «Аналіз даних», визначаємо регресійні рівняння, що описують залежність попиту від ціни $\left(\mathrm{Y}_{\mathrm{d}}=\right.$ $5500,265-0,27501 \mathrm{x})$ та пропозиції від ціни $\left(\mathrm{Y}_{\mathrm{s}}=-6957,05+0,951282 \mathrm{x}\right)$.

На підставі даних про попит та пропозицію, а також результатів розрахунку будуємо на рис. 3 графіки попиту та пропозиції.

Далі знаходимо точку, в який досягається рівновага попиту та пропозиції:

$$
\begin{gathered}
5500,265-0,27501 \mathrm{x}=-6957,05+0,951282 \mathrm{x} \\
\mathrm{x}=10158,52 \text { грн. }
\end{gathered}
$$

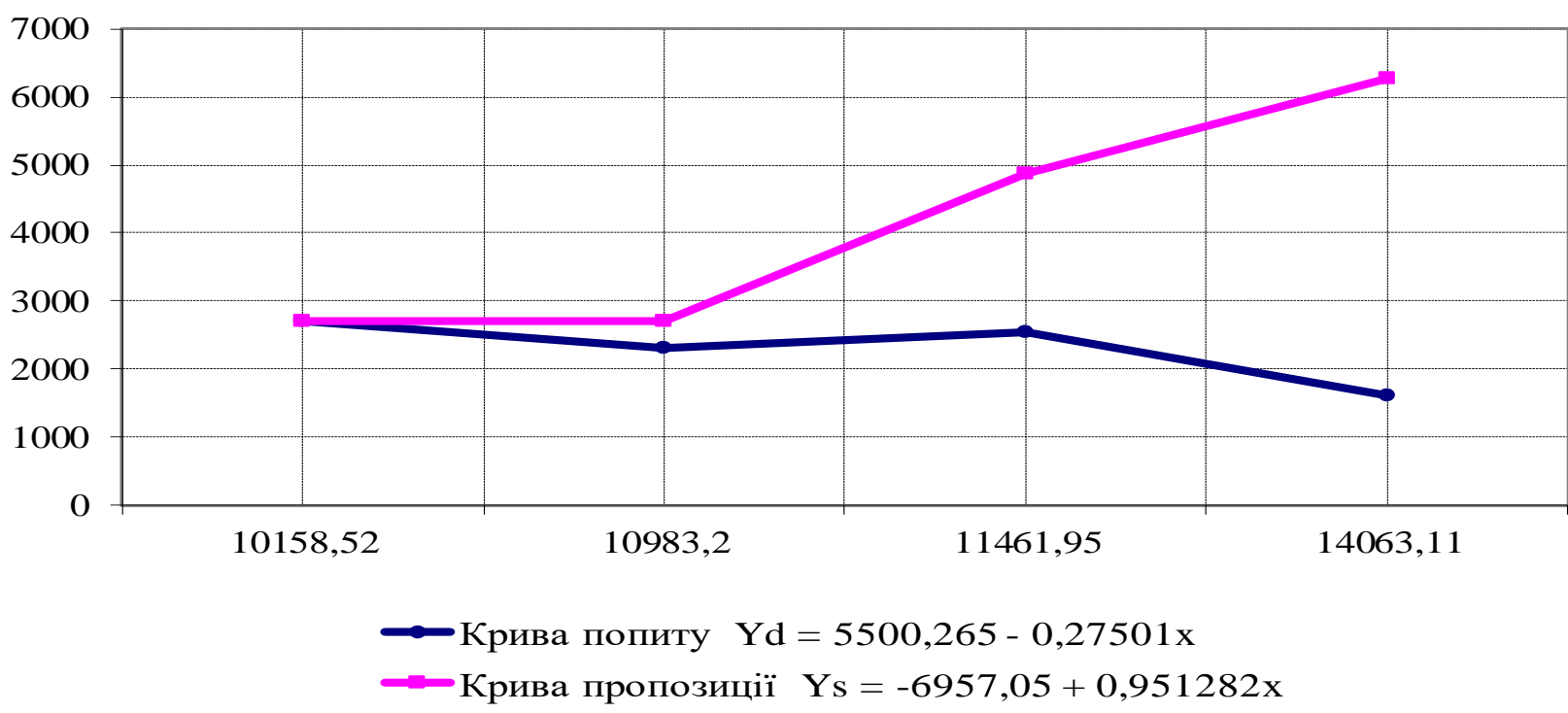

Рис. 4. Графіки попиту та пропозиції

Джерело: авторська розробка

Використовуючи результати прогнозування, підприємство має змогу виробити стратегію та завоювати більший сегмент ринку

Висновки 3 проведеного дослідження. Економічні дослідження мають основною ціллю визначення й оцінку людських потреб та вимог (попиту) 3 метою виявлення привабливих можливостей, виявлення труднощів і слабких місць у роботі підприємства. Ефективний економічний аналіз є необхідною умовою розробки планів виробництва та збуту, але він також виконується в процесі їх реалізації й контролю. Інформація, необхідна для економічного аналізу, збирається в результаті проведення практичних досліджень.

При проведенні економічних досліджень використовуються різні методи збору інформації від споживачів та від окремих експертів (фахівців виробничих підприємств, торговельних організацій) - це анкетування, опитування, інтерв'ю.

Істотну роль при обробці зібраної інформації й одержанні прогнозних оцінок грають методи математичної статистики, короткий розгляд яких під кутом їхнього практичного застосування приведено у статті.

Грунтуючись на отриманій статистичній інформації було проведено кореляційно - регресійне моделювання та побудова моделей попиту та 
пропозиції. Результати дослідження можуть бути використані на практиці при формуванні подальшої маркетингової стратегії підприємства.

\section{Перелік посилань}

1. Краснокутська Н. С. Управління потенціалом торговельного підприємства: монографія. Харків: ХДУХТ, 2016. 322 с.

2 Балабанова Л. В., Митрохіна Ю. П. Управління збутовою політикою. Київ: Центр учбової літератури, 2015. 240 с

3 Вачевський М. В. Долішній М. І., Скотний С. Г. Маркетинг для менеджера. Київ: Просвіта, 2015. 139 с.

4. Іванов Ю. Б., Тищенко А. Н., Дробитько Н. А., Абрамова О. С. Конкурентоспроможність підприємства: оцінка, діагностика. Харків: Вид. XНEУ, 2017. $256 \mathrm{c}$.

5. Шашина М. В., Кньовець В. В. Специфіка управління ризиками інвестиційної діяльності підприємств кондитерської галузі. Науковий вісник Херсонського державного університету. Серія: Економічні науки. 2018. Випуск 29(2). C. 39-42.

6. Демяненко Е. А. Тенденції розвитку кондитерського ринку України в сучасних умовах. Молодий вчений. 2016. Випуск 9 (36). С. 35-50.

7. Герасимчук В. Г. Стратегічне управління підприємством. Графічне моделювання. Київ: КНЕУ, 2017. 360 с.

8. Латкіна С. А., Тябус А. А. Шляхи підвищення ефективності збутової діяльності підприємства. Науковий вісник Ужгородського наиіонального університету. 2016. Випуск 8. Ч. 1. С.132-134.

9. Федорович Р. В. Аналіз в управлінні збутовою політикою підприємства. Тендениіі розвитку маркетингу в умовах економічних трансформацій: монографія. Тернопіль, 2017. С. 234-249.

10. Білик В. О. Саблук П. Т. Основи економічної теорії. Київ: Просвіта, 2017. $467 \mathrm{c}$.

\section{References}

1. Krasnokutska, N. S. (2012). Management of potential of the trade enterprise [Upravlinnia potentsialom torhovelnoho pidpryiemstva]: monohraph, Kharkiv: KhDUKhT, $322 \mathrm{p}$.

2. Balabanova, L. V., Mitrokhina, Yu. P. (2011). Sales policy management [Upravlinnia zbutovoiu politykoiu], Kyiv: Center for Educational Literature, P. 240.

3. Vachevsky, M. V., Dolishniy, M. I., Skotny, S. G. (2010). Marketing for the manager [Marketynkh dlya menedzhera], Kyiv: Prosvita, 139 p.

4. Svanov, J. D., Tishenko, A. N., Drobitko, N. A., Abramova, O. S. (2017). Competitiveness of the enterprise: assessment, diagnostics [Konkurentospromojnist pidpriemstva: ocinka, diagnostika], Kharkiv: KhNEU, 256 p.

5. Shashina, M. V., Knovec, V. V. (2018). Specifics of risk management of investment activity of confectionery enterprises [Spetsyfika upravlinnya ryzykamy investytsiynoyi diyal'nosti pidpryyemstv kondyters'koyi haluz i], Scientific Bulletin of Kherson State University, Series: Economic Sciences, No. 29 (2), P. 39-42. 
6. Demjanenko, E. A. (2016). Trends in the development of the confectionery market of Ukraine in modern conditions [Tendentsiyi rozvytku kondyters'koho rynku Ukrayiny v suchasnykh umovakh], Young scientist, No. 9 (36), P. 35-50.

7. Gerasimchuk, V. G. (2017). Strategic management of the enterprise. Graphic modeling [Stratehichne upravlinnya pidpryyemstvom. Hrafichne modelyuvannya], Kyiv: KNEU, 360 p.

8. Latkina, S. A, Tyabus, A. A. (2016). Ways to increase the efficiency of sales activities of the enterprise [Shliakhy pidvyshchennia efektyvnosti zbutovoi diialnosti pidpryiemstva], Scientific Bulletin of Uzhgorod National University, No 8, P.132-134.

9. Fedorovich, R. V. (2017). Analysis in the management of sales policy of the enterprise. Trends in marketing in terms of economic transformations [Analiz $v$ upravlinni zbutovoiu politykoiu pidpryiemstva. Tendentsii rozvytku marketynhu $v$ umovakh ekonomichnykh transformatsii], monograph, Ternopil, P. 234-249.

10. Biluk M. O. Sabluk P. T. (2017). Foundations of economic theory [Osnovy ekonomichnoyi teoriyi], Kyiv: Prosvita, 467 p.

\section{РЕФЕРАТИ РЕФЕРАТЫ ABSTRACTS}

\section{УДК 330.42; JEL Classification: D120}

Шершенюк О.М., Прокопенко М.В. ОСОБЛИВОСТІ ПРОВЕДЕННЯ ЕКОНОМІКО - МАТЕМАТИЧНОГО ДОСЛІДЖЕННЯ ПОТРЕБ СПОЖИВАЧІВ (ПОПИТ) ТА ЗБУТУ ТОВАРІВ (ПРОПОЗИЦІЯ) НА ПРИКЛАДІ РИНКУ ХАРЧОВОЇ ПРОДУКЦЇ̈

Мета дослідження полягає в розробці напрямів вдосконалення економічних досліджень споживчих запитів (потреб) в діяльності підприємства (фірми) за допомогою сучасних методів економіко - математичних досліджень економічних процесів, а також розробці елементів стратегії збуту продукції. Методика дослідження. Застосовані елементи експертного опитування, аналізу, економіко-математичне моделювання, регресійне моделювання, статистичні та економетричні методи аналізу: абсолютні, середні і відносні величини, індексні, трендові та регресійні факторні моделі, методи варіаційного, дисперсійного, кореляційного аналізу та графічна інтерпретація отриманих результатів. Результати дослідження. Пошук шляхів удосконалення збутової діяльності будь-якого підприємства в сучасних умовах слід розпочинати з визначення споживчих бажань і потреб. Перспективним напрямом удосконалення економічних досліджень споживчих бажань $\epsilon$ грамотне управління дослідницькою діяльністю. Основні завдання і цілі - це збір і обробка економічної інформації з подальшою розробкою математичної моделі за допомогою сучасних математико-статистичних методів. Також обгрунтована можливість використання Microsoft Excel 3 метою рішення практичних завдань визначення параметрів ринкового попиту і пропозиції. Наукова новизна. Наукова новизна отриманих результатів полягає в рішенні ряду теоретичних і практичних проблем визначення чисельних параметрів попиту та пропозиції, розробці напрямів підвищення ефективності економічних 
досліджень за допомогою сучасних математичних методів. Запропонована методика розрахунку параметрів попиту і пропозиції з допомогою економіко математичної моделі, реалізованої засобами Microsoft Excel. Практичне значення отриманих результатів. Запропоновані для впровадження результати дослідження можуть бути використані в дослідницькій діяльності будь-якого підприємства сфери виробництва і реалізації продуктів харчування. Практичним ефектом є розрахунок параметрів попиту і пропозиції залежно від споживчих потреб (параметрів товару).

Ключові слова: споживач; попит; пропозиція; потреба; економічні дослідження; Microsoft Excel.

\section{УДК 330.42; JEL Classification: D120}

Шершенюк Е.Н., Прокопенко Н.В. ОСОБЕННОСТИ ПРОВЕДЕНИЯ ЭКОНОМИКО - МАТЕМАТИЧЕСКОГО ИССЛЕДОВАНИЯ ПОТРЕБНОСТЕЙ ПОТРЕБИТЕЛЕЙ (СПРОС) И СБЫТА ТОВАРОВ (ПРЕДЛОЖЕНИЕ) НА ПРИМЕРЕ РЫНКА ПИЩЕВОЙ ПРОДУКЦИИ

Цель исследования заключается в разработке направлений совершенствования экономических исследований потребительских запросов (потребностей) в деятельности предприятия (фирмы) с помощью современных методов экономико - математических исследований экономических процессов, a также разработке элементов стратегии сбыта продукции. Методика исследования. Использованы элементы экспертного опроса, анализа, экономико-математическое моделирование, регрессионное моделирование, статистические и эконометрические методы анализа: абсолютные, средние и относительные величины, индексные, трендовые і регрессионные факторные модели, методы вариационного, дисперсионного, корреляционного анализа и графическая интерпретация полученных результатов. Peзультаты исследования. Поиск путей усовершенствования сбытовой деятельности любого предприятия в современных условиях следует начинать с определения потребительских желаний и потребностей. Перспективным направлением усовершенствования экономических исследований потребительских желаний является грамотное управление исследовательской деятельностью. Основные задачи и цели - это сбор и обработка экономической информации с дальнейшей разработкой математической модели с помощью современных математикостатистических методов. Также обоснована возможность использования Microsoft Excel c целью решения практических задач определения параметров рыночного спроса и предложения. Научная новизна. Научная новизна полученных результатов заключается в решении ряда теоретических и практических проблем определения численных параметров спроса и предложения, определены направления повышения эффективности экономических исследований с помощью современных математических методов. Предложена методика расчета параметров спроса и предложения с помощью экономико - математической модели, реализованной средствами Microsoft Excel. Практическое значение Предложенные для внедрения результаты полученных

результатов. 
использованы в исследовательской деятельности любого предприятия сферы производства и реализации продуктов питания. Практическим эффектом является расчет параметров спроса и предложения в зависимости от потребительских потребностей (параметров товара).

Ключевые слова: потребитель; спрос; предложение; потребность; экономические исследования; Microsoft Excel.

\section{UDK 330.42; JEL Classification: D120}

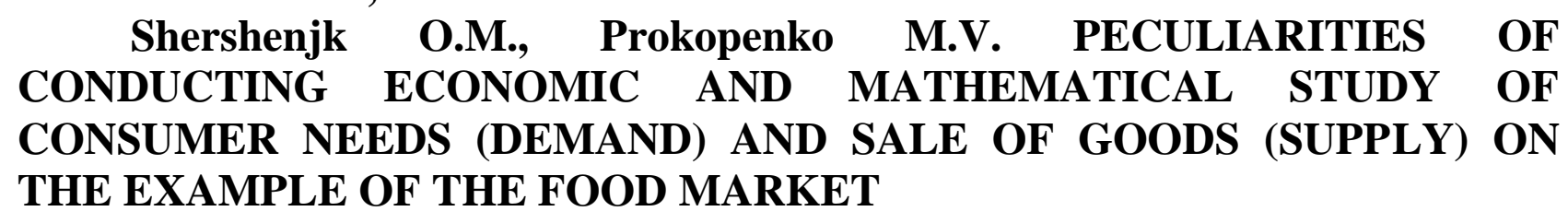

Purpose of the study is to develop areas for improving economic research of consumer demands (needs) in the activities of the enterprise (firm) using modern methods of economic - mathematical research of economic processes, as well as the development of elements of sales strategy. Methodology of research. Elements of expert survey, analysis, economic-mathematical modeling, regression modeling, statistical and econometric methods of analysis are used: absolute, average and relative values, index, trend and regression factor models, methods of variation, variance, correlation analysis and graphical interpretation of the results. Findings. The search for ways to improve the sales activities of any enterprise in modern conditions should begin with the definition of consumer desires and needs. Promising direction of improvement of economic researches of consumer desires is competent management of research activity. The main tasks and goals are the collection and processing of economic information with the further development of a mathematical model using modern mathematical and statistical methods. The possibility of using Microsoft Excel to solve practical problems of determining the parameters of market supply and demand is also substantiated. Originality. The scientific novelty of the obtained results lies in solving a number of theoretical and practical problems of determining the numerical parameters of supply and demand, identified areas for improving the efficiency of economic research using modern mathematical methods. The technique of calculation of parameters of demand and offer by means of the economic - mathematical model realized by means of Microsoft Excel is offered. Practical value. The results of the research proposed for implementation can be used in the research activities of any enterprise in the field of production and sale of food. The practical effect is to calculate the parameters of supply and demand depending on consumer needs (parameters of the product).

Keywords: consumer; demand; proposal; need; economic research; Microsoft Excel. 


\section{Відомості про авторів / Сведения об авторах / About the Authors}

Шершенюк Олена Миколаївна - кандидат економічних наук, доцент,

Харківський національний автомобільно-дорожній університет, доцент кафедри економіки i підприємництва, м. Харків, Україна; e-mail: sheralyona@gmail.com; ORCID: https://orcid.org/0000-0002-9959-2725. Моб. 050151-30-09.

Шершенюк Елена Николаевна - кандидат экономических наук, доцент, Харьковский национальный автомобильно-дорожный университет, доцент кафедры экономики и предпринимательства, г. Харьков, Украина.

Shershenyuk Elena Nikolaevna - Candidate of Science (Economics), Associate Professor, Kharkiv National Automobile and Highway University, Associate Professor, Department of Economics and Entrepreneurship, Kharkiv, Ukraine.

Прокопенко Микола Вікторович, Харківський національний автомобільно-дорожній університет, старший викладач кафедри економіки i підприємництва, м. Харків, Україна; e-mail: nvprokopenko@gmail.com; ORCID: https://orcid.org/0000-0002-4839-0154. Моб. 050-633-76-28.

Прокопенко Николай Викторович, Харьковский национальный автомобильно-дорожный университет, старший преподаватель кафедры экономики и предпринимательства, г. Харьков, Украина.

Prokopenko Nikolay, Kharkov National Automobile and Highway University, Senior Teacher at the Department of Economics and Entrepreneurship, Kharkiv, Ukraine. 